\title{
Miranda
}

Revue pluridisciplinaire du monde anglophone /

Multidisciplinary peer-reviewed journal on the English-

speaking world

15 | 2017

Lolita at 60 / Staging American Bodies

\section{Creole City: A Chronicle of Early American New Orleans.}

\section{Françoise Coste}

\section{OpenEdition}

\section{Journals}

Electronic version

URL: http://journals.openedition.org/miranda/10597

DOI: $10.4000 /$ miranda. 10597

ISSN: 2108-6559

\section{Publisher}

Université Toulouse - Jean Jaurès

\section{Electronic reference}

Françoise Coste, "Creole City: A Chronicle of Early American New Orleans.", Miranda [Online], 15 | 2017,

Online since 19 September 2017, connection on 16 February 2021. URL: http://

journals.openedition.org/miranda/10597 ; DOI: https://doi.org/10.4000/miranda.10597

This text was automatically generated on 16 February 2021.

\section{$\Theta \Theta \Theta \Theta$}

Miranda is licensed under a Creative Commons Attribution-NonCommercial-NoDerivatives 4.0 International License. 


\title{
Creole City: A Chronicle of Early American New Orleans.
}

\author{
Françoise Coste
}

\section{REFERENCES}

Creole City: A Chronicle of Early American New Orleans, Nathalie Dessens, University Press of Florida, 2015, 273 pages, ISBN number: 978-0-8130-6020-0.

1 Nathalie Dessens achieves quite a feat in Creole City: A Chronicle of Early American New Orleans, a book which is equal parts a detective story and history book. The book's starting point is quite fascinating, both from a scientific and personal points of view: a set of 158 letters, totalling almost 1200 pages, sent by Jean Boze to Jean-François Henri de Miquel, Baron de Sainte-Gême (or Henri de Ste-Gême, as he was known in the Americas) between 1818 and 1839, and forgotten for almost two centuries in the archives of The Historic New Orleans Collection. Nathalie Dessens decided to work on this correspondence when an American colleague joked to her about the tiny French town where Saint-Gême was born, Saint Gaudens-which happens to be Dessens's hometown.

2 The book reflects the material that gave it life: just like Boze, a "privileged informant" (150), wanders through the streets of New Orleans, Dessens wanders through his letters and uses his impressions and descriptions to give us a chronicle of the booming city in its first American years. The first chapter details the minute detective work Dessens had to undertake in order to understand the context in which the letters were written and to reconstruct the life of her two protagonists. This alone sent the author on an international odyssey through French, American, and Cuban archives that retraces the complex transatlantic lives of both Boze and Ste-Gême: Boze was born near Marseilles in 1753, worked in the merchant marine and made a life for himself in Saint-Domingue, where he settled in 1784, before reinventing himself as a Caribbean corsair (one who worked for the Netherlands); as for Ste-Gême, he was born in an aristocratic French 
family near Toulouse in 1767 and he devoted his life to the French army, a military career that explains his posting to Saint-Domingue. In 1803, Boze and Ste-Gême fled revolutionary Saint-Domingue (soon to be Haiti) and found refuge in Santiago de Cuba, where they met and stayed for a few years. The year 1809 saw them sail once again, this time to New Orleans, the city that had become part of the United States after the 1803 Louisiana Purchase. Boze would spend the rest of life in New Orleans, whereas SteGême finally went back to France in 1818, after making a fortune, particularly thanks to a sugar plantation he had acquired though his wife's family. Boze was one of his associates, as he seemed to have helped Ste-Gême manage his Louisianan business, especially after his departure which had made him a rather typical transatlantic absentee owner. The correspondence at the heart of the book allowed the two friends to remain connected across the ocean and to exchange on the many financial assets Ste-Gême had left behind, like his dozens of slaves, who are a recurring topic in the letters. These many "epic" episodes and this long friendship help show how "the Atlantic was a space of crossroads, a complex network of commercial movements, of departures and returns, of transatlantic families and correspondence" (2).

The scientific potential of the letters is undeniable, as this "breathtaking Atlantic narrative" (19) provides an extensive description of New Orleans in its first American years, a period of "intense political competition between the French-speaking community and the new American rulers" (27) that is too often neglected by historians. Thanks to Boze's letters, Nathalie Dessens demonstrates how this transition period was marked by "a complex dialectic of continuity and change" (3). Each chapter of the book stresses one facet of New Orleans and shows how the city was slowly, but irrevocably, integrated by the United States, while proudly retaining a strong Atlantic and Caribbean dimension.

During the twenty years covered by the correspondence, the small French colony of New Orleans became the third largest city, and the first exportation port, in the United States, which came with extensive growing pains. Thus, Boze chronicles the urban transformation of New Orleans, where conditions of life were often horrendous, especially because of violent and extreme weather, the constant spectre of yellow fever and cholera epidemics which took regular tolls on the local population, and the extremely high rate of violent crime that went together with the arrival of tens of thousands of immigrants and sailors from all over the Atlantic world-a topic which seems to have exerted a peculiar fascination on Boze, whose letters "tee[m] with stories of people beaten to death, shot, stabbed, and killed in every imaginable way" (52). But local authorities persistently endeavoured to improve urban life, and one feels Boze's pride in the efforts put in sanitation, public lighting, transportation or cultural institutions (like theatres) which made New Orleans a glaring urban and commercial exception in the South and "the only modern city in the West" (86).

The growth and prosperity of the city was closely linked to the geopolitical upheaval triggered by the Louisiana Purchase. Boze's letters cannot be understood without taking into account the fact that the city in which he and Ste-Gême had arrived in 1809 was now part of the United States. The correspondence consequently depicts "the beginning of the decline of the French cultural domination over the city, but also the first moments of the creation of a new culture, an era of both Americanization and Creolization" (28). The letters allow Nathalie Dessens to study the complex power dynamics between the many demographic groups composing the city, like the large 
community of free people of color, or the Creoles who had to adapt to the Americanization of their city. Given his personal position, Boze also regularly insists on the economic competition between the French-speaking and American communities. Hence a double movement at play in Boze's letters: on the one hand, the city retained extremely strong connections with its French roots, if only through the personal bonds between French citizens who had stayed in Louisiana like him, and those who had gone home, like Ste-Gême, or the continual arrival of thousands of immigrants from all over France, even after the Purchase. The letters show how interested Boze had remained in his home country, in particular through the countless mentions of political events in France and in Europe (the Greek War of Independence, the conquest of Algeria, the reign of King Louis Philippe or the Three Glorious Days of July 1830). However, even if such concerns may indicate a certain degree of nostalgia for the homeland, Boze's letters also betray an almost unconscious Americanization at work, particularly through the expression of strongly liberal and anti-monarchical values. The letters thus reveal "a man of in-betweenness", a man of "dual belongingness" (149).

Boze's letters are an extraordinary find, as they are a testament to the many changing faces of the city in the 1820s and 1830s. This archival discovery is made even better by the impressive mastery of the history of New Orleans by Nathalie Dessens, who regularly indicates how Boze's descriptions fit in the existing historiography of the city. This leads her to groundbreaking research on some forgotten topics, like dueling, in particular in all its racial dimensions (chapter 2). She also knows how to give the reader a window into a man's private life, as she manages to recreate Bose's moods and very human emotions, as in the pages devoted to his love for gossip (in chapters 3 and 5 for instance). But the personal and the anecdotal never take over scientific concerns and, in the last chapter, Nathalie Dessens returns to the key question of Creolization as she finds in the letters "the progressive hybridization of various cultures" (189), including the Gallic and Anglo-American ones. People from the two communities spoke together (in English, a language which increasingly appears in Boze's letters though the years), traded together, went to the same entertainment venues, lived in the same neighborhoods, celebrated together (particularly the anniversary of the Battle of New Orleans), and even sometimes married one another. Based on Boze's testimony, Dessens disagrees with previous generations of historians who liked to insist on how French speakers "resist[ed] an imposed American way." According to her, "the idea of a forced Americanization needs to be qualified" (211); instead, "New Orleans residents chose the best of coexisting systems" (199), as the period described in Boze's letters "show[s] a clear progression toward the elaboration of a new cultural continuum, borrowing from both dominant cultures, in which the two main groups often met halfway, building, in the process, a new, original culture" (211)-a thesis more than convincingly demonstrated in this chronicle of early American New Orleans. 
INDEX

Mots-clés: Nouvelle-Orléans, correspondance, monde transatlantique, urbanisation,

Créolisation

Keywords: New Orleans, correspondence, transatlantic world, urbanization, Creolization

\section{AUTHORS}

\section{FRANÇOISE COSTE}

MCF - HDR

Université de Toulouse 2-Jean Jaurès

francoste@hotmail.com 